\title{
Factors Influencing ESL Students' Selection of Intensive English Programs in the Western United States
}

Katie Briana Blanco

Brigham Young University

Follow this and additional works at: https://scholarsarchive.byu.edu/etd

Part of the Arts and Humanities Commons

\section{BYU ScholarsArchive Citation}

Blanco, Katie Briana, "Factors Influencing ESL Students' Selection of Intensive English Programs in the Western United States" (2018). Theses and Dissertations. 7697.

https://scholarsarchive.byu.edu/etd/7697

This Thesis is brought to you for free and open access by BYU ScholarsArchive. It has been accepted for inclusion in Theses and Dissertations by an authorized administrator of BYU ScholarsArchive. For more information, please contact ellen_amatangelo@byu.edu. 
Factors Influencing ESL Students' Selection of Intensive English Programs in the Western United States

Katie Briana Blanco

A thesis submitted to the faculty of

Brigham Young University

in partial fulfillment of the requirements for the degree of

Master of Arts

Mark W. Tanner, Chair

William G. Eggington

K. James Hartshorn

Department of Linguistics

Brigham Young University

Copyright (C) 2018 Katie Briana Blanco

All Rights Reserved 


\author{
ABSTRACT \\ Factors Influencing ESL Students' Selection of Intensive English Programs \\ in the Western United States \\ Katie Briana Blanco \\ Department of Linguistics, BYU \\ Master of Arts
}

Intensive English Programs (IEPs) play an important role in helping speakers of other languages gain necessary language, cultural, and educational skills to succeed in an Englishspeaking environment (Hamrick, 2012; Toner, 2017). Previous research has investigated factors that influenced student choice of IEPs located in the southeastern portion of the U.S. (Williams, 1994) and in California (Jones, 2013). This study identified factors that influenced ESL students who chose to further their English language education at IEPs located in the western United States. Particular influences that were probed included program, location, student services, and marketing factors. Moreover, this study examined the previously uninvestigated relationship between factors that influence student choice and the size of the program in which students enroll. A Qualtrics survey was used to gather data and was modeled on the questionnaires of previous studies investigating IEP students' choice of program (Jones, 2013; Williams, 1994).

Results indicated that with regard to program factors, participants highly valued IEPs that provided an intense learning experience, were well respected, and had excellent teachers. Location factors of greatest importance were the safety of the school and community, and the good reputation of the city where the program is located. Students perceived that the most important student services that programs offered were academic or personal counseling, immigration services, and out of class activities. The marketing factors that were rated highest in importance were the program's website, referrals from former students, and the ability to communicate online with the school. A surprising finding was that social media appeared to be of minimal to moderate importance in influencing students' decisions, but of the platforms investigated, Facebook was identified as the most influential. Implications of these findings are then discussed for program directors of IEPs seeking to attract new students as well as maintain and grow their respective programs.

Keywords: Intensive English program (IEP), English as a Second Language (ESL), marketing, international students, enrollment 


\section{ACKNOWLEDGEMENTS}

I am deeply grateful to my mentor and thesis chair, Dr. Mark Tanner, for helping me through this entire thesis process. He has helped me develop as both a scholar and an individual. I could not have completed this thesis without his unfailing patience and his determination to continue moving forward which motivated me beyond my own endurance at times. I would also like to thank my committee members, Dr. James Hartshorn for all of his thoughtful feedback and especially for taking the time to help me whenever I had yet another question about the statistical analysis process, and Dr. Bill Eggington for the time and sacrifices he made to participate on my committee, for his insightful suggestions, and also for giving me the opportunity to participate in the data collection on the English Language study abroad.

I am extremely thankful for my parents who taught me as a child that I can do hard things and for instilling in me a commitment to finish what I start. I am also very appreciative of my

friends and coworkers who have continually empathized with me and encouraged me throughout this long process.

Finally, I am especially grateful to my husband, Abram, for his constant love and support as we have walked this road together. His kind, encouraging words and actions have carried me through many nights of discouragement. 


\section{TABLE OF CONTENTS}

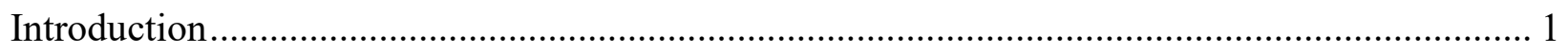

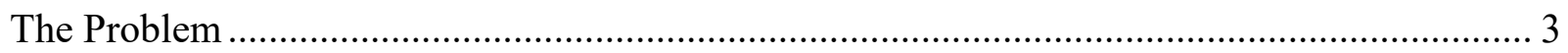

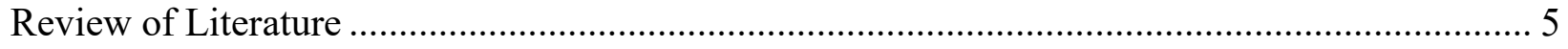

Characteristics of Intensive English Programs................................................................. 5

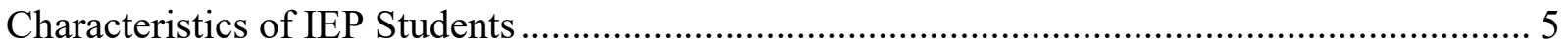

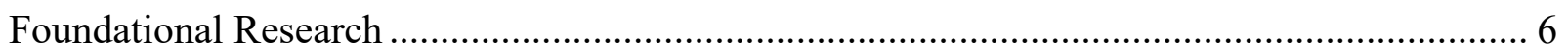

Marketing Intensive English Programs ......................................................................... 7

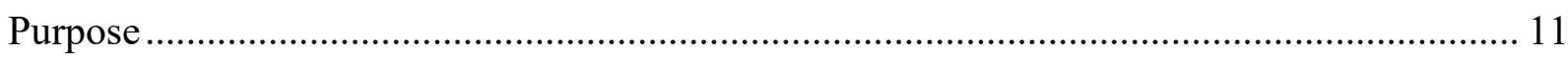

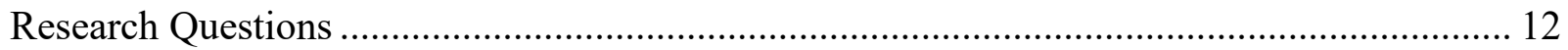

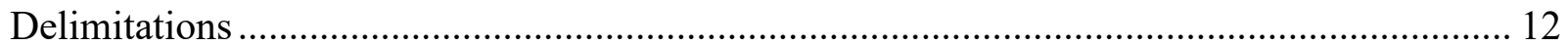

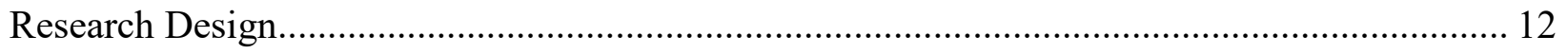

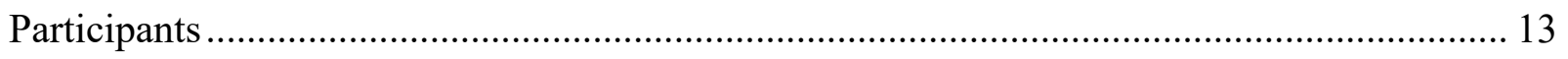

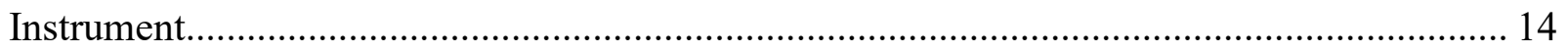

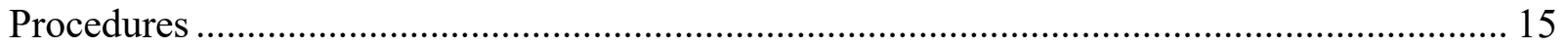

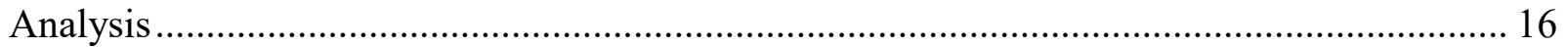

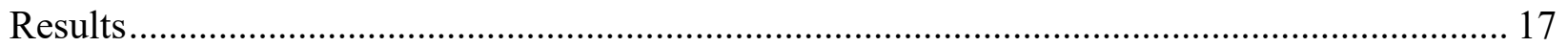

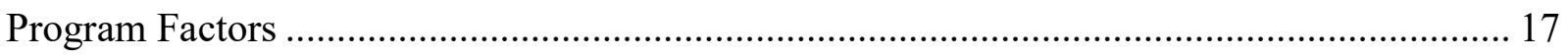

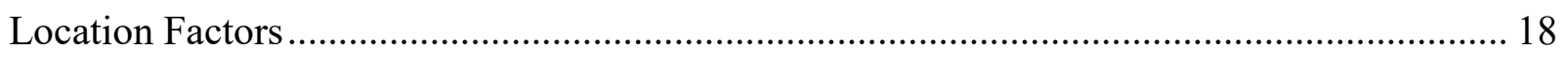

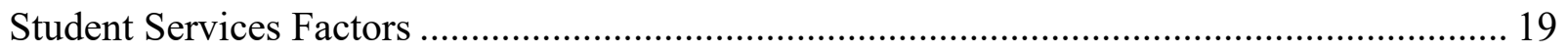

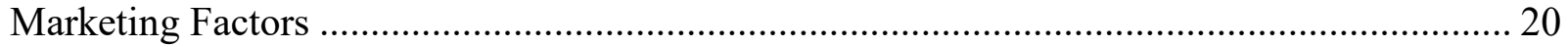

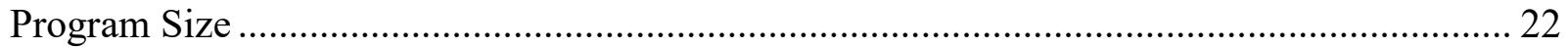

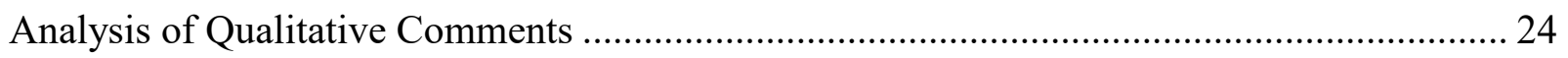

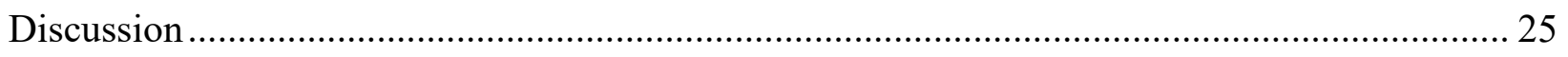

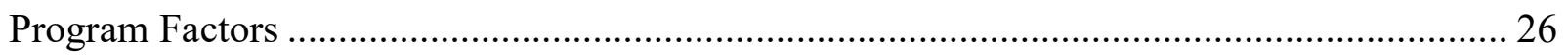

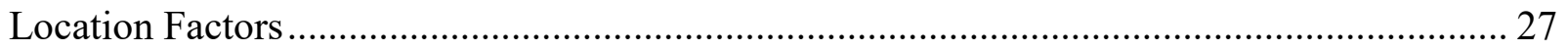

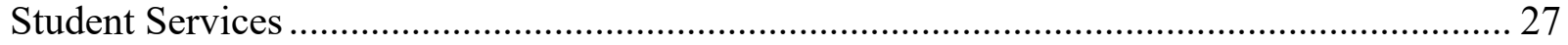

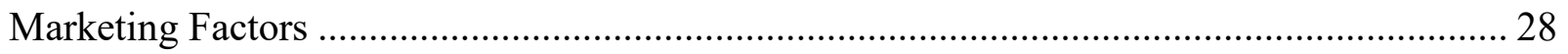

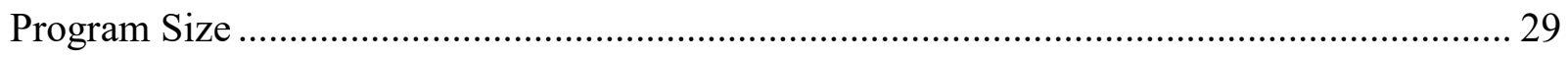

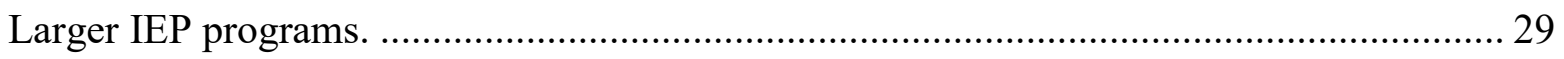

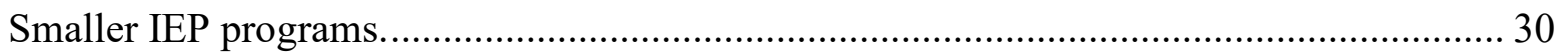




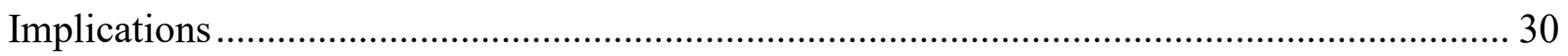

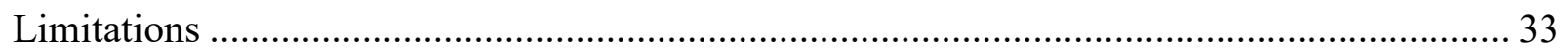

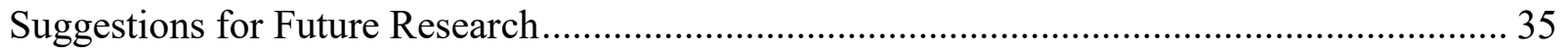

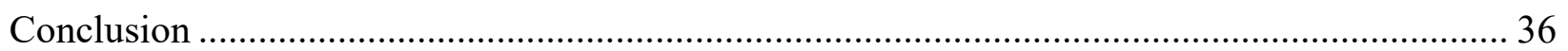

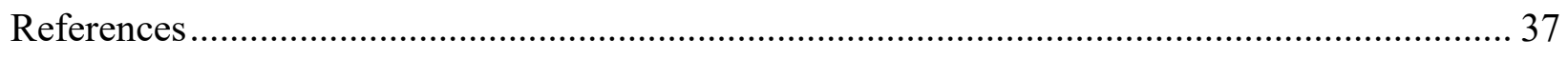

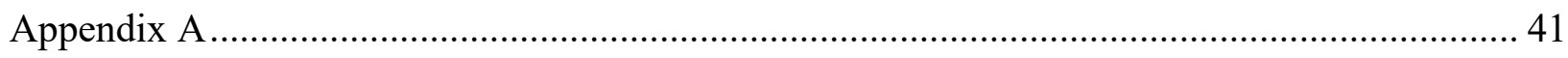

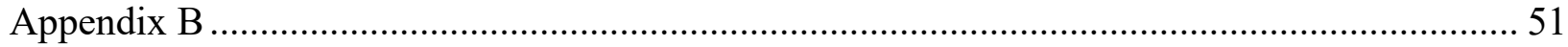




\section{LIST OF TABLES}

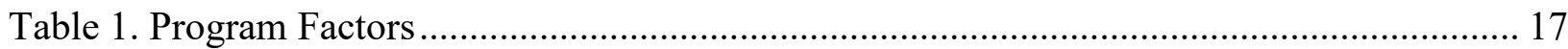

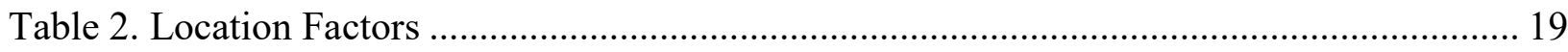

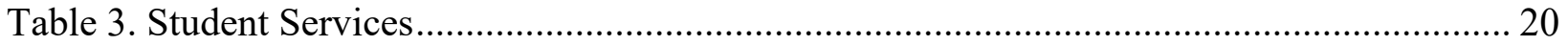

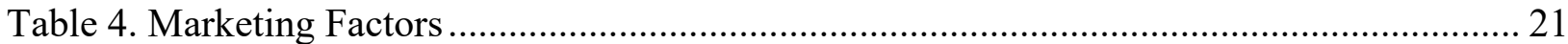

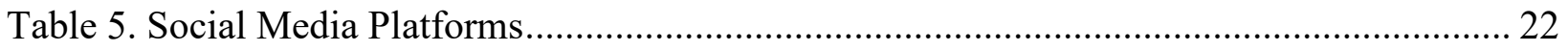

Table 6. Regression Analysis Showing Factors Associated with Program Size ....................... 23

Table 7. Taxonomy of Student Choice Factors from the Open-Ended Survey Question............ 25 


\section{PREFACE}

This thesis was written to partially fulfill the MA TESOL degree at Brigham Young University and was written in such a way that it could be submitted as a manuscript for publication. It is the goal of Brigham Young University's Department of Linguistics to help students in the MA TESOL program to publish their research in academic journals. As such, TESOL Journal was selected as a possible publication venue given that this journal focuses on publishing data-based research that is applicable for a broad audience of TESOL practitioners, including teachers and program administrators. Readers of TESOL Journal may find this study helpful as they work with ESL learners and programs in the process of program design, marketing, and curriculum development.

The submission requirements for TESOL Journal state that a feature article should be approximately 8,500 words, which is why this thesis manuscript is shorter in length than a traditional thesis manuscript. With a total word count of just over 10,000 words, some editing would be required to bring this manuscript in line with the journal's overall word count. The additional requirement for publication in TESOL Journal is that manuscripts should be prepared according to the Publication Manual of the American Psychological Association (6th edition). This thesis complies with this requirement.

Other possible target journals for this thesis manuscript include ELT Journal and TESLEJ. These journals are possible venues for publication due to their broad focus on theoretically grounded research and extensive readership, which includes teachers and administrators of ESL programs. 


\section{Introduction}

Adriana debated whether to choose an English Language program in her country or to leave her home, family, and friends to travel to a new location with a new culture to study English. While there was a variety of programs to choose from in her home country, her goal was to learn English quickly in hopes of attending an American university and getting her MBA degree. She thought studying in an English-speaking country would help her learn English more quickly, but there were so many different programs to choose from and she was not familiar enough with the United States to select a reputable program that would help her achieve her goals. As she considered this dilemma, she met an old friend who had recently returned from studying in the United States. As they chatted, Adriana mentioned that she was trying to decide on an English school to attend. Her friend began to tell her about the school he had attended and recommended that she apply there. With so many questions to consider-Where would she live? Who would she live with? Was it safe to travel to an unfamiliar city without knowing anyone there? - she relied heavily on her friend for information. Eventually she decided to attend the same program he had recommended.

Intensive English programs (IEPs) play an important role in helping speakers of other languages gain necessary language, cultural, and educational skills to succeed in an Englishmedium university (Colón, 2016; Toner, 2017), to develop language skills necessary for employment requirements (Hamrick, 2012), or to develop essential communication skills to be able to function in an English-speaking country (Hamrick, 2012). Many students who enroll in IEPs are international students seeking to improve their English before moving on to further their educational or professional goals. 
In 2016, the number of international students enrolled in the United States exceeded one million for the first time (Institute of International Education, 2017a). Data from the Institute of International Education (IIE) (2017a) also shows that international student enrollment in U.S. colleges and universities has been steadily increasing since a slight three-year decline following the terrorist attacks on the World Trade Center in 2001. Furthermore, the rate of international student enrollment has increased each year by an average of $6.7 \%$ for the past ten years (Institute of International Education, 2017a).

In 2017, the portion of international students enrolled in IEPs across the United States was approximately $8 \%$ of the total international student body (Institute of International Education, 2018). International students in IEPs contributed to the 36.9 billion dollars that international students infused into the U.S. economy in the 2016-2017 academic year (NAFSA, 2018b) and they play an important role in enriching communities where they live by contributing to the economy and bringing an abundance of talents and innovative ideas (Heaney, 2009; NAFSA, 2018a). Until recently, the number of IEP students continued to follow the rising trend of international student growth until a sudden divergence in 2016 when IEP enrollment dropped abruptly. That year, while total international student enrollment continued to grow, IEP enrollment declined from 133,335 students in 2015 to 108,433 in 2016. Furthermore, IEP enrollment continued to decrease in 2017 to a low of 86,786 students, a 20\% decrease from 2016 (Institute of International Education, 2018). This drop was the biggest decline since 2001 to 2002, when enrollment decreased $34.8 \%$ from 78,521 to 51,179 students (Institute of International Education, 2017a). Bain, Luu, and Green (2006) predicted that increased international market competition, changing perceptions of the United States, and policy changes in international countries would lead to a decrease of international students in the United States. 
Moreover, the IIE Center for Academic Mobility Research and Impact cited a combination of factors that have influenced this recent decline including visa application issues or denials, costs of U.S. higher education, the social and political environment, and the increasingly competitive global market of higher education options (Institute of International Education, 2017b).

This shift in IEP enrollment suggests that program administrators must be aware of those factors that influence international students' decision making in regard to why students choose to attend one program over another and how particular program features may attract students to a specific location. With the market becoming more competitive for IEPs seeking to attract students due to lower international student enrollments in the U.S. (Institute of International Education, 2018), data about students' choices could prove very valuable to administrators seeking to promote their program in a competitive market. After all, decreased enrollment could mean lowering teacher salaries or even reducing the number of employees in a program (Soppelsa, 2012, p. 151). These results could in turn lead to fewer courses being offered and may even culminate in a program being unable to sustain itself. The decrease in IEP student enrollment has placed increased pressure on language program administrators to identify what factors have influenced student selection of the program they choose to attend and to improve the strategic planning for their program (Christison \& Murray, 2008).

\section{The Problem}

Since most IEPs are fueled by student tuition (Hamrick, 2012; Panferov, 2008), maintaining and expanding student enrollment in a program is of critical importance. Knowing what factors have attracted students to enroll in a school may be a means of not only helping enhance current students' experiences, but also of attracting future students. However, without 
knowing what factors have attracted students, administrators may be left to rely on intuition and their own experience to promote their program.

Only a limited number of studies have investigated factors influencing students' choice of ESL program. These studies have largely addressed regional areas of the U.S. One of the first to investigate this topic was a study by Williams (1994) which investigated factors that influenced ESL students' choice of program in the southeastern part of the United States. In this study, a total of 314 IEP students from 9 programs were surveyed to determine which factors influenced their selection of the IEP in which they were enrolled. The results of this study indicated that the quality of the program, having qualified native-speaker teachers, and the safety of the community were the most influential factors affecting students' choice of program. Given that over 24 years have passed since this study was conducted and that there continue to be ongoing major changes in geo-political and economic situations worldwide including advances in technology, the Internet, and marketing practices, updated research into factors that influence students' choice of IEP is very timely.

In 2011, another study was done involving IEPs, but the focus of this study (Jones, 2013) assessed the effectiveness of marketing factors used by ESL programs. Whereas Williams (1994) focused on the southeastern United States, Jones (2013) examined the marketing factors of 10 IEPs located in San Diego, California. After collecting data from 335 ESL students, Jones reported that the most influential marketing factors were the school's website, referrals from former students, and referrals from travel or educational agents.

The current study performed an updated analysis of present-day factors influencing students' choice of IEP by building upon the studies performed by Williams (1994) and Jones (2013). The current study was designed to probe factors influencing students attending IEPs 
located in the western U.S. and additionally investigated the influence of the internet and social media applications in students' decision making. Given that IEP enrollment sizes vary greatly, this study further explored how program, location, student services, and marketing factors relate to students' choice of program in connection with program size.

\section{Review of Literature}

\section{Characteristics of Intensive English Programs}

An IEP may be privately owned or may be connected to a university (Hamrick, 2012, p. 322) and they are generally able to flexibly set their own program calendars and term lengths (Franklin, 2009, p. 146). Although an IEP may be connected to a university, most IEPs are responsible for their own marketing and funding and are primarily funded by program fees paid by students enrolled in the program (Franklin, 2009; Hamrick, 2012, Panferov, 2008). In addition, IEPs usually have around 18 hours of instruction each week. IEP students generally enter the U.S. on an F1 visa and thus are required to be enrolled in full-time English language study, which is defined by visa regulations as 18 hours or more per week (Hamrick, 2012, p. $321)$.

\section{Characteristics of IEP Students}

Students who attend IEPs have some common characteristics. IEP students are generally international students who travel abroad to improve their English as a means of opening a gateway to other opportunities such as additional education or better employment. Another group of IEP students simply come to get to experience the culture while improving their language skills (Hamrick, 2012; Mazzarol \& Soutar, 2002). Students enrolled in IEPs have a broad range of ages. Most are college aged (18 to 30), although there are many students who may be quite a bit older than the average age and some who are a bit younger. Due to their age, IEP students 
may share characteristics with students described in Kasworm's (2003) study in which she examined differences between undergraduate students of various ages and found that young adult students (defined as 24 years and younger) and adult students (defined as 25 years and older) participate in education differently due to differing life experiences and expectations. She explains that age, maturity, developmental complexity, and differing roles and life responsibilities influence adult learners to enroll more in programs that have accessible admission, that offer flexibility in course scheduling, are supportive of life commitments, are relevant to their stage of life, and that are cost-effective (p. 7). These differences tend to lead adult learners to more part-time programs whereas younger students may not face similar life complexities and so are able to enroll in full-time programs without issues.

\section{Foundational Research}

In what appears to be the first empirical study analyzing student choice of intensive English program, Williams (1994) looked specifically at university-affiliated IEPs in the southeastern United States and sought to identify factors that influenced international students in their selection of a university-related IEP. He investigated program factors, affiliated university factors, student services factors, location factors, and personal factors. In his analysis, he rated the relative importance of each factor and analyzed variations in factor preferences between different genders, ages, and cultural groups. He additionally focused on discovering which student service factors and institutional policy factors affected students' choice of program. Williams surveyed 314 students who were enrolled in high intermediate and advanced level classes at nine university-affiliated IEPs in the southeastern United States and found that the top three factors of most importance to students were the quality of the program, qualified nativespeaker teachers, and safety of the community. In addition, his data analysis showed that there 
were significant differences between language groups in the perceived importance of academic aspects (e.g. the quality of the program and teachers, TOEFL preparation, and curriculum, etc.), influence of others (e.g. information about the IEP available in the student's home country, a recommendation, or having a friend or family member in or nearby the IEP, etc.), and university services (e.g. housing, food services, and recreational facilities available, etc.). Williams (1994) found that Thai speakers rated factors in the academic category higher on average than other language groups. In addition, Chinese speakers had the highest mean ratings for factors related to influence of others while Japanese speakers rated factors in university services highest on average compared to other language groups. The analysis of gender showed that there was a statistical difference in importance of academic aspects, with females placing more importance on academic aspects than males. There were also statistical differences in the importance of university services by age, with students younger than 25 years placing more importance on university services such as housing and food service. Finally, he found that student services (e.g. housing services, food services, counseling, etc.) and institutional policies (e.g. conditional admission or guaranteed admission) were not as important as expected, with their level of importance falling below a moderate level of importance.

\section{Marketing Intensive English Programs}

Because most IEPs — both independent and university-based — are responsible for their own financial security, IEP administrators have the challenging responsibility of ensuring that their program has a steady revenue and a robust student enrollment. This responsibility requires that administrators be aware of current and potential incoming student patterns, recognize economic and political conditions, notice marketing trends, perform promotional activities, analyze budgets, predict and prepare for future demands, make decisions about when or when 
not to expand a program, or even fundraise (Brady, 2008; Franklin, 2009; Hamrick, 2012; Panferov, 2008). Although these responsibilities are broad and rather complex, there are some strategies that administrators can use to fulfill these demands.

For an overview of some basic marketing strategies, Eaton (2002) and Panferov (2008) offer a variety of ideas that can help program administrators through the marketing process. Before promoting a program, Panferov (2008) recommends doing a program analysis that includes surveying students for recommendations to improve the program. As part of the program analysis, Eaton (2002) recommends defining the language program (or creating a mission statement), creating a program image, setting goals, and identifying the target market. Panferov (2008) also points out the need to identify where marketing the program might be most fruitful. It is also essential to carefully assess the financial situation of the program to know how much of the budget should be spent on marketing (Panferov, 2008).

When using promotional materials, Eaton (2002) advises emphasizing benefits of the program, creating clear, easily accessed promotional materials, and making it easy to contact the program. Panferov (2008) also recommends using a mix of print and electronic materials to meet the various needs of locations around the world. She additionally cautions that when using physical paraphernalia to market a program such as shirts, keychains, or posters, it is wise to first, consider the quantity needed and the cost of producing these items, and second, to avoid trendy pieces and specific dates that can quickly cause them to become outdated.

When actively promoting a program, Panferov (2008) recommends using a mix of direct and indirect marketing methods, and perhaps offering a discount to students who refer new students. Eaton (2002) emphasizes the strength of developing good relationships with anyone who is involved with the program to improve program reputation and to draw in potential 
students. Jones (2013) stresses that connecting through personal relationships is extremely advantageous in marketing due to the power of word-of-mouth advertising.

A vital aspect of fulfilling marketing responsibilities includes ensuring that limited marketing budgets are being used effectively. If administrators hire a marketing professional, they must confirm that the professional has extensive experience dealing with international and non-native English-speaking populations (Franklin, 2009). This is especially important when developing material and picture content for promotional resources due to the potential for misunderstandings from differing cultural interpretations. What may seem straightforward to a materials developer may be unclear to a potential patron due to cultural color significance, ambiguity in photos, or poor text translation (Jenks, 1991). An additional question to consider is whether or not to translate promotional materials. Administrators must determine if it is costeffective to hire professional translators to produce high-quality translations of promotional materials into various languages. Although these translations may assist in recruitment for specific language groups, they may limit where promotional materials may be distributed (Panferov, 2008). Considering how to best distribute marketing funds can ensure that resources are used effectively.

Another simple strategy a program can pursue is to diversify their student population (Franklin, 2009; Panferov, 2008). Jenks (1991) emphasizes the need to frequently market program services internationally and to provide students with quality language instruction, which can improve the reputation of the program. Franklin (2009) states that administrators should "continually study the environment, the competition, and also their own programs to remain successful" (p. 152). By studying their own programs and surveying their own students, administrators can benefit greatly by gaining information about why students chose to come to 
their program. Administrators can then use this information to highlight the aspects of the program that drew in students.

Finally, an essential piece of a program's promotional process is to evaluate how effective marketing practices have been (Panferov, 2008). This step could be done in a variety of ways, one of which could be to survey incoming students to find out how they learned about the program. In addition to reviewing how successful a promotional strategy was, it is necessary to then plan how to adjust in the future (Eaton, 2002).

In an effort to gain greater insight into the influence of ESL program marketing practices and their effectiveness, Jones (2013) conducted a study specifically addressing which marketing factors had the greatest impact on a student's choice of English language program. Whereas Williams (1994) investigated factors drawing students to programs in the southeastern United States, Jones performed his research on the opposite side of the country in California, looking solely at marketing. The purpose of his study was, first, to investigate how important various marketing aspects were in influencing students' decisions to study at an ESL school and, second, to investigate the relationships between the effectiveness of marketing factors and gender, age, region of citizenship, and reasons for studying English. To answer these questions, Jones administered a survey to 335 students from 10 ESL schools in San Diego and found that the most influential marketing elements appeared to be the school's website, referrals from former students, and referrals from travel or educational agents. He also found that the rank order of importance for each of these factors varied depending on students' region of citizenship, with ESL directory listings being highly rated by Asian and Middle Eastern students, a mailed brochure being highly rated by European students, and a U.S. embassy referral being highly rated by students from Latin America. In regard to age, younger students rated the importance of 
educational agent referrals higher while older students gave more importance to referrals from former students. Finally, there did not seem to be many differences in importance of factors between genders with the exception of two factors being rated higher by females. The first was mailed brochures and the second was blogs, chatrooms, and Twitter. These findings from Jones (2013) provide valuable information for programs seeking to improve their marketing strategies.

\section{Purpose}

The studies by Williams (1994) and Jones (2013) provide essential foundational information to IEP program administrators seeking to maintain or grow their programs. These studies, however, acknowledge that they have left out other regions of the U.S. in their search for answers and add a caution with generalizing their findings beyond the scope in which the data was collected. In addition, because technology has changed so rapidly, some of the factors they investigated may be outdated.

The intent of the current study was to further investigate factors influencing ESL students in their choice of IEP by providing data for an additional region of the United States, the western region. Moreover, a previously unexamined variable of critical importance is how factors that influence student choice relate to the size of the program students attend. There are a variety of IEP sizes with some having more than 100 students and others having fewer than 50 students. A crucial question that has not been researched in the literature is whether there are differing factors that influence international students to enroll in a program with a smaller enrollment versus those who attend programs with student bodies in excess of 100 students.

As Panferov (2008) explained, research regarding student enrollment and program administration is very valuable for IEP administrators because they often lack training and knowledge of how to optimally market their program. Administrators make decisions regarding 
the allocation of funds for marketing and recruitment practices, technology enhancement, and teacher recruitment and training. If they can be better informed as to what factors draw students to their programs, they can use their limited recruitment and advertising budgets much more wisely.

\section{Research Questions}

The following research questions were investigated in this study:

1. How important were the following factors in influencing ESL students' selection of IEP?
a. Program
b. Location
c. Student services
d. Marketing

2. How do selection criteria differ for ESL students according to the size of IEP?

\section{Delimitations}

There were multiple parameters on the breadth of this study. Given that other studies have investigated factors influencing ESL students' choice of IEPs in California and in the southeastern portion of the U.S., this study concentrated solely on gathering data from IEPs located in states in the western region of the U.S.

\section{Research Design}

The purpose of this study was to analyze which factors most strongly influenced ESL students in their choice of IEP. An online survey was used to collect data from students in IEPs of varying sizes located in two western states in the United States, Wyoming and Utah. The survey was initially distributed to 54 IEPs located in five western states, but representatives from only 8 programs chose to participate in the data collection, resulting in 179 student survey 
responses. In an effort to respect program anonymity, individual participating programs will not be identified. Unfortunately, only 147 of those responses were from students attending a program that could be considered intensive in nature. To qualify, students needed to be enrolled in a program where they were studying a minimum of 15 or more hours of English language coursework per week.

\section{Participants}

Participants in this study were ESL students enrolled in IEP programs in Wyoming and Utah who were identified by their programs as being at an English proficiency level of intermediate, advanced, and superior. Rationale for only including intermediate and higher level students was first, to build upon the research of Jones (2013) and Williams (1994) in which they both included students of intermediate and higher proficiency levels. A second reason for including students at these levels in the data collection was to ensure that all survey participants would sufficiently understand the survey in order to accurately respond. The demographic data was all self-reported by participants. There were 87 females and 87 male participants coming from 35 different countries. Fifteen different languages were represented, with the most common being Spanish (52.9\%), Portuguese (15.5\%), Chinese (8.6\%), Japanese (5.2\%), French (4\%), and Korean (3.4\%). The following languages represented less than $2 \%$ of the population: Arabic, Burmese, Haitian Creole, Fante, Mongolian, Polish, Russian, Thai, and Turkish. Participant age was divided into two categories, 24 years and younger and 25 years and older. These age categories were chosen to replicate Williams' (1994) study and are additionally supported by Kasworm (2003), who explains that adult students (defined as 25 years and older) participate in higher education differently than do young adult students (24 years and younger) due to age, maturity and developmental complexity, and differing roles and responsibilities. The sample 
population included 84 participants who were age 24 and younger and 90 participants age 25 and older.

\section{Instrument}

An online Qualtrics survey was developed to capture which program factors had drawn students to enroll in the IEP they chose. The survey consisted of four sections that focused on program, location, student services, and marketing factors with participants rating the importance of a total of 68 factors distributed between those sections. In addition, it also included seven demographic questions at the beginning of the survey and a section at the end of the survey inquiring about their reasons for studying in the U.S. Before students were able to begin the survey, they saw a statement that described the purpose of the survey, explained how their data would be used, described the incentive, stated that participation was completely voluntary, and that the completion of the survey provided consent for their data to be included as part of the study. Following the consent form, the survey first gathered demographic information and then asked an open response question inquiring about the main reason students had chosen to attend their current ESL program. The survey then listed factors related to the ESL program, the location, program student services, and marketing. Participants rated how influential each factor was on a five-point Likert scale, which included the following responses: "This factor was not at all important (1), I considered this factor, but it was not very important (2), This factor was moderately important (3), This factor was important (4), This factor was very important (5)" (see Appendix A for survey). Permission was obtained from the university's institutional review board (IRB) to collect data with this instrument.

The survey for this study was based on surveys created by Williams (1994) and Jones (2013). Both of the previous studies first gathered information by surveying students and 
administrators with open-ended questions to determine which factors had influenced students' decisions to attend the ESL program in which they were enrolled. Previous studies then constructed their surveys based on the responses of the students and administrators. The survey for this study was created by incorporating the factors that the previous studies had analyzed, while adding additional marketing questions to take into account advances in technology, especially with social media. After the survey was constructed, it was reviewed by experienced ESL instructors to ensure that students at an intermediate level would be able to understand the wording. Next, the survey was piloted at a university-affiliated IEP with 27 ESL students at the intermediate and higher levels of proficiency. After the students took the survey, slight changes in wording were made to six questions to improve clarity.

\section{Procedures}

A list of 54 ESL programs located in Idaho, Wyoming, Nevada, Utah, and Colorado was compiled using internet searches and directory lists because they appeared to be intensive programs. Programs were not included in the list if they were labeled as community ESL programs because students are not required to attend at least 18 hours of class per week in a community program. Any program that couldn’t be identified as a community program was included in the list. If a program administrator's contact information was not listed on the program's website, the program was called to obtain it. Program administrators were contacted by email or by phone, inviting them to allow their programs to participate in the study. Due to a generous research grant from Brigham Young University, a total of 12 gift cards were purchased and all participating program administrators and students who chose to participate were put into a drawing for one of these cards. The administrators had a one in four chance of winning a $\$ 50.00$ gift card and the students had a one in 25 chance of winning a $\$ 15.00$ gift card. The 
primary email sent to the program administrators described the purpose of the study and how the collected data would be used in addition to a link to the Qualtrics survey. Subsequent weekly emails encouraged each program to participate and additionally included a copy of the information from the initial email, unless a program had opted out of the study. The data collection period was originally planned to take four weeks, but a low response rate necessitated extending the collection over a three-month period as follow-up emails, phone calls, and personal visits were required to secure participants. Eight programs chose to participate in the data collection. However, upon reviewing the survey response data, any responses that were not from intensive programs were excluded from the data. The participating program directors were called to obtain a close estimate of how many students were attending their program to determine program size in order to perform the regression analysis on the data.

\section{Analysis}

The quantitative data collected from the Qualtrics survey was analyzed using measures of central tendency (frequencies, means, and standard deviations) as well as a repeated measures analysis of variance (ANOVA). Using the Likert scale numerical values for each factor, the mean score for each value was used to place factors in a rank order. Means, standard deviations, $p$-values, and effect sizes are reported for each item. A stepwise regression analysis was used to answer the second research question regarding program size.

After responding to a series of demographic questions, students then answered one openended survey prompt which asked, "What was the main reason you chose to come to your current ESL (English as a Second Language) program?" The qualitative comments obtained from this question were tagged for key words and then initial categorizations were created based on patterns that emerged in the data using a Grounded Theory Approach (Titscher, Meyer, 
Wodak, \& Vetter, 2000). A random sample of ten percent of the responses were tagged by a secondary rater to ensure that there was interrater reliability in category placement. There was $89 \%$ agreement between the raters.

\section{Results}

The results for each research question factor will be reported separately.

\section{Program Factors}

The first research question explored the level of importance regarding varying program features in ESL students' choice of IEP. A repeated measures analysis of variance was used with a Greenhouse-Geisser correction to adjust for a lack of sphericity. The results were statistically significant, $F(8.08,1349.50)=40.85, p<.001$. Table 1 presents the mean scores and standard deviations for the factors in order of importance.

Table 1

\section{Program Factors}

\begin{tabular}{lll}
\hline Program Factors & M & SD \\
\hline Intense learning experience & 4.27 & 1.00 \\
The program is well respected & 4.25 & 1.07 \\
The teachers are regarded as excellent & 4.17 & 1.11 \\
Individual attention & 4.14 & 1.06 \\
The program offers TOEFL preparation & 4.13 & 1.17 \\
Variety of classes & 4.05 & 1.00 \\
The program has good resources & 3.99 & 1.13 \\
Class times are convenient & 3.99 & 1.14 \\
Right number of class levels for my plans & 3.92 & 1.16 \\
Program is part of a college I want to attend & 3.83 & 1.34 \\
Students from many different countries & 3.71 & 1.26 \\
Class sizes are small & 3.67 & 1.26 \\
The cost is low & 3.60 & 1.27 \\
Few students who speak my L1 & 2.90 & 1.52 \\
Many from home country or who speak same L1 & 2.67 & 1.50 \\
\hline
\end{tabular}

Note. The mean scores reported are the results from participants rating the importance of factors on a 5-point Likert scale. 
The most important program factor selected by students in their consideration of which IEP to attend was the perception that the program provided an intense learning experience. This factor was closely followed by the program being well respected. Other factors high on students' list of importance included a program having excellent teachers, individual attention being provided, and the program offering TOEFL (Test of English as a Foreign Language) preparation. All of these factors were rated on average between important and very important on the Likert scale. While the top three factors were not statistically significant from each other, the top factor did differ significantly from the four lowest rated factors. Pairwise comparisons with a Bonferroni adjustment showed that an intense learning experience differed significantly from reasons such as having small class sizes $(p<.001, d=.527)$, having a low cost $(p<.001, d=.586)$, having few students who spoke the same L1 $(p<.001, d=1.06)$, or having many students from the same country or who spoke the same L1 $(p<.001, d=1.26)$. The effect size ranged from medium to large.

\section{Location Factors}

The second series of factors investigated in students' selection criteria were location factors. The results of a repeated measures ANOVA with a Greenhouse-Geisser correction were statistically significant, $F(6.64,1102.03)=31.86, p<.001$. Table 2 displays the associated descriptive statistics listed in rank order of means. 
Table 2

Location Factors

\begin{tabular}{lcc}
\hline Location Factors & $M$ & $S D$ \\
\hline Safe community & 4.16 & 1.13 \\
School is in safe part of city & 4.12 & 1.19 \\
City has good reputation & 3.89 & 1.18 \\
Low cost of living & 3.59 & 1.32 \\
City is multicultural & 3.47 & 1.42 \\
Convenient local transportation & 3.41 & 1.38 \\
Size of the city & 3.35 & 1.45 \\
Friend or family member in city & 3.29 & 1.56 \\
City has good weather/climate & 3.25 & 1.31 \\
Friend or family member in ESL program & 2.56 & 1.57 \\
\hline
\end{tabular}

The top three location factors identified by students included the safety of the community, the school being in a safe part of the city, and the good reputation of the city where the program is located. These top three factor means were all rated close to "This factor was important." The top factors were not statistically different from each other. Nevertheless, there were significant differences between the highest rated location factor and the bottom three factors of having a friend or family member in the city $(p<.001, d=.639)$, the city where the program was located having good weather $(p<.001, d=.744)$, and having a friend or family member in the ESL program $(p<.001, d=1.17)$. The effect size for these factors ranged from medium to large. This was shown through Pairwise comparisons with a Bonferroni adjustment.

\section{Student Services Factors}

The third series of factors examined in students' selection of IEP focused on student services. The results of a repeated measures ANOVA with a Greenhouse-Geisser correction were statistically significant, $F(4.90,818.17)=38.89, p<.001$. Table 3 provides the mean scores and standard deviations for each of the factors. 
Table 3

Student Services

\begin{tabular}{lll}
\hline Student Services Factors & M & SD \\
\hline Academic or personal counseling & 3.51 & 1.39 \\
Immigration services & 3.49 & 1.41 \\
Out of class activities & 3.37 & 1.36 \\
Help to find housing & 3.07 & 1.45 \\
School offers meal plans & 2.98 & 1.56 \\
Offers homestay with American family & 2.57 & 1.43 \\
Airport pickup & 2.32 & 1.42 \\
\hline
\end{tabular}

None of the student services factors were rated by students in the very important to important range. The top four factors fell into the moderately important range with the services of homestays and airport pickup being "not very important." The repeated measures ANOVA did show, however, that the top factor was statistically different in importance from the bottom two factors of being able to homestay with an American family $(p<.001, d=.667)$ and the program picking up the student from the airport $(p<.001, d=.847)$. These factors had a medium to large effect size.

\section{Marketing Factors}

The fourth series of factors examined in students' selection of IEP addressed the importance of various marketing factors. The results of a repeated measures ANOVA with a Greenhouse-Geisser correction were again statistically significant, $F(8.33,1365.45)=17.68$, $p<.001$. Table 4 shows the accompanying mean scores and standard deviations for these items. 
Table 4

Marketing Factors

\begin{tabular}{lll}
\hline Marketing Factors & M & SD \\
\hline The school's website & 3.62 & 1.31 \\
Referral from former student & 3.50 & 1.30 \\
Communicating online with the school & 3.38 & 1.39 \\
ESL directory list & 3.02 & 1.40 \\
Educational fair & 3.01 & 1.47 \\
Referral from school & 2.96 & 1.37 \\
Watching a video produced by school & 2.96 & 1.48 \\
Referral from employer & 2.93 & 1.43 \\
Mailed brochures or information packets & 2.93 & 1.39 \\
News Article or TV news report & 2.87 & 1.41 \\
Referral from U.S. embassy & 2.82 & 1.42 \\
Referral from agent or recruiter & 2.76 & 1.38 \\
Poster or flier about the school & 2.72 & 1.41 \\
Newspaper or magazine advertisement & 2.70 & 1.44 \\
Watching video not produced by school & 2.64 & 1.38 \\
\hline
\end{tabular}

In rating the importance of marketing factors, students identified the school's website, a referral from a friend, and online communication with the school as moderately important factors. The remaining list of factors were identified by students as being less important with the bottom three factors being significantly less important than the top factor, shown by comparing the school's website with the lowest three factors, which were a poster or flier about the school $(p<.001, d=.661)$, newspaper or magazine advertisement $(p<.001, d=.668)$, or watching a video that was not produced by the school $(p<.001, d=.728)$. These factors had a medium effect size.

In addition to the marketing factors listed above, a follow-up research question sought to investigate the importance of social media in its impact on ESL students' choice of IEP. In a repeated measures ANOVA with a Greenhouse-Geisser correction, results comparing six 
different social media platforms proved statistically significant, $F(3.26,518.21)=47.82, p<.001$.

Table 5 shows the associated descriptive statistics.

Table 5

Social Media Platforms

\begin{tabular}{lll}
\hline Social Media Platforms & M & SD \\
\hline Facebook & 2.88 & 1.57 \\
Instagram & 2.38 & 1.48 \\
Blog & 1.93 & 1.25 \\
Snapchat & 1.87 & 1.22 \\
Twitter & 1.76 & 1.16 \\
Reddit & 1.59 & 0.98 \\
\hline
\end{tabular}

While Facebook was statistically more important than the rest of the social media platforms, the effect size was small between Facebook and Instagram $(p<.001, d=.328)$. However, the effect size increased to medium when Facebook was compared to blogs $(p<.001$, $d=.669)$ and Snapchat $(p<.001, d=.718)$, and to large when compared to Twitter $(p<.001$, $d=.811)$, and Reddit $(p<.001, d=.986)$. Of the social media platforms investigated in this study, Facebook was significantly different, but the mean scores given by the students put it in the category of "not very important."

\section{Program Size}

The second research question was posed in an effort to see what factors contribute the most toward the decision to attend a large IEP. Using a stepwise linear regression analysis, the data was analyzed to see which factors - out of 68 variables - were associated with students who chose to attend a large program compared to those factors that were associated with students who chose to attend a smaller program (see Appendix B for the list of variables that were not shown to be associated with program size). Programs with an enrollment over 100 were considered 
large, programs with 50-100 students were considered medium, and programs with fewer than 50 students were considered to be small. With an adjusted $\mathrm{R}^{2}$ of .471 , this regression analysis accounts for just under half of the variability associated with program size. Table 6 presents the associated statistics.

Table 6

Regression Analysis Showing Factors Associated with Program Size

\begin{tabular}{lrrrr}
\hline Factors & \multicolumn{1}{c}{$B$} & \multicolumn{1}{c}{$S E$} & $\beta$ & $p$ \\
\hline (Constant) & 250.203 & 43.766 & & $<0.000$ \\
My purpose is mainly for vacation & 20.564 & 5.138 & 0.373 & $<0.000$ \\
ESL program is in a larger school I want to attend & 21.616 & 4.866 & 0.354 & $<0.000$ \\
ESL program provides intense learning experience & 23.335 & 8.428 & 0.264 & 0.007 \\
The city has a good reputation & 14.302 & 5.528 & 0.201 & 0.011 \\
The school offers airport pickup & -9.540 & 4.255 & -0.157 & 0.027 \\
The city has convenient local transportation & -10.821 & 5.023 & -0.162 & 0.033 \\
English will help me get a good job someday & -15.637 & 6.777 & -0.171 & 0.023 \\
There are many students who speak my L1 & -9.641 & 4.050 & -0.175 & 0.019 \\
The ESL program is well respected & -16.888 & 8.057 & -0.197 & 0.038 \\
There is a good exchange rate with the U.S. dollar & -14.210 & 4.994 & -0.252 & 0.005 \\
Higher Proficiency level & -43.179 & 10.117 & -0.312 & $<0.000$ \\
\hline
\end{tabular}

The standardized beta $(\beta)$ column in Table 6 represents relatively how much each factor contributes to the overall model. The factors with positive $\beta$ values at the top of the table are most strongly connected with choice of a large program, while those factors at the bottom of the table with negative $\beta$ values are most strongly connected with student choice of a smaller program. The factors in the middle of the table that have values closer to zero, though still meaningful, are less important than those factors at the top and bottom of the table. Students who agreed that their purpose for learning English was mainly for a vacation were strongly associated $(\beta=0.373)$ with being enrolled in a larger program. Another factor important to students in large programs was that their ESL program is part of a larger college or university that they would like to attend. Additionally, higher proficiency students were more strongly associated with being 
enrolled in smaller programs. Students in smaller programs also seemed to be more concerned with the economics of their study abroad given that the exchange rate between their country and the U.S. was a reason for their choice of a smaller program.

\section{Analysis of Qualitative Comments}

In the survey, one open-ended question was included that invited students to identify the main reason they chose to go to their current ESL program. Of the 174 survey responses, all of them included a response to this question. The comments were categorized using a Grounded Theory approach (Titscher et al., 2000) according to keywords and the main ideas included in each response. Some responses were separated into two or more categories due to the use of multiple keywords and ideas being included.

The primary reason $(28.5 \%$ of the responses) that students gave for selecting their current IEP was for the purpose of improving their English. This response shows that students appear to realize their need to attend a school that will improve their English-language proficiency. However, the purpose of this open-ended question was to have students identify the single most important program factor overall that influenced their program choice, not their purpose for attending an English program. It is possible, however, that students were implying that they believed the school they chose to attend would help them learn English better than other program options. The second most frequent answer (26.6\%) involved selection of a school because the student believed the program would help them achieve their goal of furthering their education and/or obtaining an advanced degree. Other reasons for choosing their current program involved enabling them to obtain future or better employment $(9.8 \%)$, to attend a program with a good reputation (8.4\%), and environmental factors (8.4\%) such as studying in an English-speaking country or to be surrounded by people with similar standards and beliefs. The remaining 
responses included the affordability of the program (3.2\%), preparing for a better life $(2.3 \%)$, and self-improvement (1.4\%). A complete list of categories with example statements is included in Table 7. There were six responses that could not be categorized due to incomplete and unclear expression of ideas. These items were eliminated from the data analysis.

Table 7

Taxonomy of Student Choice Factors from the Open-Ended Survey Question

\begin{tabular}{lll}
\hline Categories & $n$ & Representative Response \\
\hline Improve English & 61 & "I want to improve my English." \\
Pursue Education & 57 & "To be able to go to college here in the states." \\
Pursue Employment & 21 & "Improve my English to find a good job." \\
Program Reputation & 18 & "I researched about ESL program in [location name] and I found \\
& & it has good ratings." \\
Environment & 18 & "I decided to come here because I thought that if I went to a \\
& country that only speaks English I will learn more, and I was \\
& right."
\end{tabular}

Note. Grammar in participant responses edited for clarity.

\section{Discussion}

The purpose of this study was to determine which program, location, student services, and marketing factors were of most importance to students selecting to study in IEPs located in the Western U.S. This study was designed to build upon the previous findings from Williams (1994) and Jones (2013). This study also investigated factors influencing students' choice of IEP related to program size. 


\section{Program Factors}

The first research question explored how important varying program factors were in ESL students' choice of IEP. The results from the quantitative survey data showed that students felt that their choice of program was largely influenced by whether the program provided an intense learning experience, the reputation of the program, and a reputation of excellent teachers. These factors were not statistically significant from each other, but they were all rated above four on a five-point Likert scale indicating that these factors were all important for ESL learners. These responses indicate that students are making critical choices about where to study based on the quality of the learning experience and the reputation of the program. The next three factors help clarify additional elements related to the quality of the program - individual attention, TOEFL preparation, and having a variety of classes. The top factors were also supported by students' qualitative comments that emphasized students' strong desire to improve their English skills and to study in a program with a good reputation. Another factor that was rated as important and was supported by the students' qualitative comments included the importance of the program offering TOEFL preparation so that students could pursue advanced degrees. The TOEFL is a required standardized test for international students hoping to attend an American college or university. Williams (1994) also found that the perceived quality of the program and having qualified teachers were important factors influencing ESL learners' choice of program.

Surprisingly, the cost of the program was not identified in the present data as being an important factor influencing student choice. This factor did receive some support in the qualitative comments, but affordability of the program was only identified by $4 \%$ of the students as being a factor seriously impacting their overall choice of program. Other factors of less 
importance for ESL students were studying in a program where there were few students who spoke their same L1 or of having many students from their same country.

\section{Location Factors}

Within the category of location, the key theme that surfaced as being important to students was that of safety. Students identified a safe community, a safe school setting, and the good reputation of the city in which the program was located to be some of the most important location factors. These three factors were not statistically significant from each other, but it is interesting to note that these factors were statistically different from other factors which learners said were not necessarily important, such as having friends or family in the same city, having good weather, and having friends or family in the same program. These results add support to Williams' (1994) study in which he found that the safety of the community was in the top three most important factors influencing students' choice to attend an IEP in the southeastern part of the United States. These results clearly suggest that for international students coming to the United States to study English, safety is an important factor no matter where the program is located.

\section{Student Services}

In the category of student services, no factors were rated as "important" or "very important." There were a few factors, however, that students identified as "moderately important" in their selection of an IEP. These factors included academic or personal counseling, immigration services, and out of class activities. In Williams' (1994) study of students attending IEPs in the southeastern part of the United States, respondents also indicated that academic or personal counseling, assistance with immigration matters, and out of class activities were the most important student services factors 25 years ago. The least important services that students 
rated as not being very important included schools offering a homestay with an American family and airport pickup.

\section{Marketing Factors}

Another important area investigated in this study was that of marketing factors. Three factors that students identified as being moderately important to important in their selection included the school's website, referrals from former students, and the ability to communicate online with the school. Four percent of students identified in the open-ended question that their ESL program had been referred to them, as exemplified by a student response that said, "My friends recommended this school to me. After research I figured this is the best option for good money." These results highlight the importance of a school having a website that provides students with clear program information and a means of communicating with the school online. The referrals that previous students provide for a program also appear to be of equal importance. It seems that students searching for an IEP value the experience that former students have had in the program. In Jones' (2013) study of marketing factors influencing student selection of IEPs in California, he found that the school's website and referrals from former students were some of the most important factors that influenced students' choice of IEP. However, he found that another factor-referrals from agents-was also important. In the current study, the factor "referrals from agents" was rated as not being very important. In contrast, the current study did find that students felt the ability to communicate online with the school was one of the more important factors. The marketing factors of lowest importance were posters or fliers about the school, newspaper or magazine advertisements, or watching videos not produced by the school.

To probe the issue of marketing further, the survey investigated students' perceptions of how important major social media platforms were in shaping their decision. In an era where 
communication through social media platforms seems to be a daily phenomenon, knowing the level of importance of these platforms and their use in program selection could be particularly important in deciding where to spend advertising and marketing dollars. It was surprising to learn that although social media is used world-wide to market products and its use is regularly promoted as key in marketing (Husain, Ghufran, \& Chaubey, 2016), the data from this study suggests that social media platforms are not as important as one might anticipate in influencing students' decisions to attend an IEP. The highest rated social media app, Facebook, was only rated as moderately important in students' choice of program. Other social media apps such as Instagram, Blogs, Snapchat, Twitter, and Reddit appeared to have little to no importance in student selection.

\section{Program Size}

The second research question investigated how the selection criteria for programs may have differed for students based on the size of the program they were attending. The answer to this question was studied by using a stepwise linear regression analysis comparing the program factors against the size of the program the student was attending, large or small.

Larger IEP programs. In order to be considered as a large IEP, student enrollment was identified as having over 100 full-time equivalents (FTEs). The regression analysis showed that for students attending a larger school, a desire for a vacation accounted for the most variance associated with the choice of a large IEP compared to other variables. This suggests that learning English for a vacation appears to be important to many students in large programs. It is unclear whether students felt that by attending a larger school, there would be more opportunities for vacation, or whether the student would be able to more easily miss class and take time off to vacation without being missed. This factor warrants further study. Other factors that had a high 
variance for students attending larger programs was that the ESL program was located within a larger college or university. With the frequency of open-ended responses citing attendance of an IEP for the purpose of furthering education or achieving an advanced degree, students attending larger IEPs may feel that this type of program would give them better access to a larger and more reputable academic institution.

Smaller IEP programs. Small IEPs were identified as having a student enrollment of fewer than 50 FTEs. The regression analysis indicated that students who were at a higher proficiency level were strongly associated with being enrolled in a smaller program. This may be explained by high proficiency students possibly desiring individualized attention for their specialized needs as they prepare for their next educational or professional step. It's also possible that this finding is due to many of the high proficiency students seeking to keep their visa active by attending an inexpensive and flexible program while they decide which educational program or future goal they would like to pursue. The other factor that was strongly associated with students attending a smaller program was having a good exchange rate between the U.S. dollar and the student's home currency. This might be due to students taking advantage of favorable economic conditions to learn English at a program that may be less expensive than a larger program. This finding is interesting because in the general survey responses, cost did not appear to be of major importance to the majority of ESL students.

\section{Implications}

The findings from this study have important implications for IEP directors and administrators. Since most of the funding that supports IEPs tends to come from student tuition and fees (Murray, 2012), it is critical that programs identify ways to ensure that enrollment remains robust and that careful budgeting and strategic planning is incorporated (Christison \& 
Murray, 2008) to help guide a program's success. The findings from this research suggest that IEPs located in the western part of the U.S. continue to provide a quality, intensive learning experience for their students. Much of this can happen as they maintain a program that is well respected (Eaton, 2002) and one that hires excellent teachers (Williams, 1994). In addition, students indicate that curriculum content should include periods of individual attention such as tutoring, TOEFL instruction, and a variety of classes. As for location, students' comments indicate that issues of safety are a primary concern. They want to be enrolled in a school that is located in a safe community, and the location is one that has a good reputation. Of moderate importance are a city that is affordable, is multicultural, and has a good transportation system. In regards to student services, programs would be wise to have academic counseling available for students (Middlebrook, 1991) as well as immigration services and a variety of out-of-class activities that provide a social environment for their students. In marketing their program, administrators should make their school's website a source of important information for potential students as well as a means whereby interested students can contact school personnel with questions. Students also value referrals from former students and the ability to communicate online (through the website or email) with the school. Social media apps were found to be less important as tools for marketing respective programs, but of those surveyed, Facebook was the most often utilized.

Other marketing considerations administrators should consider include ensuring that the layout of the website is intuitive and user friendly. Photos should be professional quality. Because referrals from former students are so important, it may be useful to include a section for student testimonials on the website. Finally, as students communicate online with the school, it 
would be beneficial to have a staff member assigned to provide prompt responses to emails or online communication with prospective students.

Finally, administrators should also consider the size of their program and how this factor attracts students to their respective school, as well as how the program can fill a niche in the market. For example, based on the regression analysis, many students attending a large program are also motivated to take a vacation. It is unclear if students feel that they may be less noticed in a larger program and therefore may be able to take more time off from studying. Larger IEPs are usually located in larger cities as well, so this comment could possibly reflect students' feelings that in a larger city, there may be more activities available outside the school setting. Further investigation of students' attitudes regarding vacations is needed. Students attending a large IEP also mentioned that an important criterion for them was that the ESL program was connected to a larger college or university and that it provided an intensive learning experience. These comments seem to reflect the adage, "Bigger is better."

If a student is coming to a program mainly for a vacation, there may be some creative ways program directors can meet the students' desires to study in an excellent school, but also take advantage of what a large city offers. Some examples could be to include English learning field trips in the curriculum, or social activities where ESL students could regularly meet with local native speakers to practice their English. Additionally, programs could give students assignments to participate in cultural experiences through attending local events.

The quantitative findings regarding those attending a large school were also supported by the qualitative data. In the most frequent responses to the open-ended question, students indicated that they wanted to improve their English and to pursue advanced degrees. Both of these factors would be ones that students could achieve at a larger institution. 
For those attending a smaller institution, there appeared to be a strong connection to students with higher proficiency levels. A small school may provide students with a more personal learning experience, providing more individualized support to help them better achieve their English language learning goals. Another factor that was strongly connected with students attending smaller IEPs was that they felt there was a good exchange rate between the U.S. and their home country. While the actual exchange rate of a country's currency is influenced by a number of factors, it is possible that students attending smaller schools felt that their money went further because the cost of living was cheaper than it might be in a larger program.

It is important for program directors and administrators to carefully consider specific program, location, student services, and marketing factors that may be influencing students attending their respective IEP as well as issues related to program size. Administrators are encouraged to continue collecting data (Panferov, 2008) that can be used to make informed decisions.

\section{Limitations}

Even with the valuable results identified in this study, this research was not without limitations. One limitation involved the number of programs participating in the survey. The researcher contacted 54 different English language programs located in five western states, but it is not known why some programs chose not to have their students participate. Drawings for 12 Amazon gift cards were done to provide incentives for both program administrators and students to participate. Program directors were also informed that data from the study would be shared directly with them. In addition, most programs that were contacted expressed great interest in the research, yet regardless of interest, many of them still did not participate. Communicating with a few program directors in face-to-face meetings and over the phone revealed that some directors 
were hesitant to participate in the research due to concerns about maintaining competitiveness in the market. Some feared that sharing program data would weaken their advantage and explained that their program's sustainability was dependent on their ability to compete with other IEPs. Other program directors simply chose not to participate because the timing of their semester made it difficult to distribute the survey to their students. Many programs said they would participate and then either did not distribute the survey to their students or none of their students chose to take it. Further possible reasons for programs not participating could have been simply due to difficulties in getting approval from multiple levels of administration. It may also be that the administrators were simply busy and forgot to distribute the survey to their students. An additional possibility may be that some programs feared that survey results would reflect negatively on their program and so chose not to participate. In order to get greater cooperation for future studies of this type, future researchers must resolve the issue of cooperation that apparently prevented some programs from participating.

The demographics of survey respondents lead to another limitation. Because the majority of participants were from Spanish and Portuguese language groups, the study results may favor factors that are of high importance to speakers of those languages. While other language groups may place greater importance on other factors, there was an insufficient number of subjects from those language groups to draw conclusions based on the participants' L1.

In addition to the small number of programs participating, some programs had a very small number of participants complete the survey. In a few cases, only one student from a program participated. It is unclear whether there were issues in distributing the survey link to students, or if students may have started the survey and then not completed it for fear that it would take too much of their time. 
A third limitation occurred when some programs had students complete the survey, but upon evaluating the survey responses, it was determined that the program did not meet the “intensive" program requirement, so the program's data was not included in the analysis.

While having survey respondents complete an open-ended response was valuable, it was clear from the responses that some students misinterpreted the question. As mentioned previously, rather than identifying the single most important factor influencing their choice of a specific IEP program, $35 \%$ of the students simply indicated that their motivation to come to an IEP was to improve their English. A further questionnaire would need to clarify this question or ask additional open-ended questions in an effort to avoid misunderstandings.

\section{Suggestions for Future Research}

Presently, there appear to be ongoing global factors and circumstances that impact international students entering the United States to study (Institute of International Education, 2017b). These factors include changes in government regulations regarding the availability of visas for students from particular countries, concerns about health and welfare, changes in economic stability and currency of nations, and the cost of studying abroad. As data suggests that the number of students attending IEPs is declining (Institute of International Education, 2017a), program directors may desire to know those factors that draw students to their respective school to shape how they promote their program and increase enrollment. Based on the experience gained through this study, it is recommended that in future research investigating IEP factors, principle investigators should first obtain contact information such as specific email addresses or phone numbers for program directors. Researchers must also realize that web directories may be out of date and there may have been personnel changes in programs. It may also be necessary to provide more significant incentives for program directors to encourage students in their 
respective programs to participate. Finally, it may be necessary to translate the survey into multiple languages if there is a desire to capture data from students who are at the novice proficiency level and who may have great difficulty completing a survey in English. Given that this study initiated the inquiry into program selection factors that may be differentiated based on program size, this factor needs further investigation with additional student participation from programs that are both large and small in enrollment.

\section{Conclusion}

The purpose of this study was to investigate the importance of factors that influence ESL learner choice of IEP. Four categories were investigated - program, location, student services, and marketing factors - in addition to investigating which factors are associated with program size. Ongoing research into these factors needs to be done in an effort to help existing as well as new programs cope with changes in the global marketplace and economies as well as attitude shifts towards immigration and international travel. The number of students attending a program also impacts the financial well-being of the institution as well as its ability to hire qualified teachers, establish and maintain an excellent reputation, implement a responsive and engaging curriculum, and effectively utilize technology in language teaching and in marketing their program. 


\section{References}

Bain, O., Luu, D., \& Green, M. (2006, October). Students on the move: The future of international students in the United States. Retrieved from American Council on Education website: https:/www.acenet.edu/news-room/Pages/Students-on-theMove.aspx

Brady, B. (2008). Development, a.k.a. fundraising: A neglected element of professional development. In C. Coombe, M. L. McCloskey, L. Stephenson, \& N. J. Anderson (Eds.), Leadership in English language teaching and learning (pp. 154-166). Ann Arbor, MI: University of Michigan Press.

Christison, M. \& Murray, D. (2008). Strategic planning for English language teachers and leaders. In C. Coombe, M. L. McCloskey, L. Stephenson, \& N. J. Anderson (Eds.), Leadership in English language teaching and learning (pp. 128-140). Ann Arbor, MI: University of Michigan Press.

Colón, V. (2016). A framework for international student participation in postsecondary U.S. English language programs. Commission for International Adult Education. Retrieved from ERIC database. (ED581844)

Eaton, S. E. (2002). 101 ways to market your language program: A practical guide for language schools. Calgary, Canada: Eaton International Consulting.

Franklin, S. K. (2009). Intensive English programs. In L. Heaney (Ed.) NAFSA's guide to international student recruitment ( $2^{\text {nd }}$ ed., pp. 145-152). Washington, DC: NAFSA. Hamrick, J. (2012). Intensive English programs. In M. Christison \& F. L. Stoller (Eds.), A handbook for language program administrators (2 ${ }^{\text {nd }}$ ed., pp. 321-328). Miami Beach, FL: Alta Book Center. 
Heaney, L. (Ed.) (2009). NAFSA's guide to international student recruitment ( $2^{\text {nd }}$ ed.). Washington, DC: NAFSA.

Husain, S., Ghufran, A., \& Chaubey, D. S. (2016). Relevance of social media in marketing and advertising. Splint International Journal of Professionals, 3(7), 21-28.

Institute of International Education. (2017a). International student enrollment trends, 1948/492016/17. Retrieved from Open Doors Report on International Educational Exchange website: http://www.iie.org/opendoors

Institute of International Education. (2017b). November 2017: Fall 2017 international student enrollment survey (joint survey). Retrieved from Open Doors Report on International Educational Exchange website: http://www.iie.org/opendoors

Institute of International Education. (2018). IEP students and student-weeks by place of origin, 2015-2017. Retrieved from Open Doors Report on International Educational Exchange website: http://www.iie.org/opendoors

Jenks, F. L. (1991). Designing and assessing the efficacy of ESL promotional materials. In M. C. Pennington (Ed.), Building better English language programs (pp. 172-188). Washington, DC: NAFSA.

Jones, E. S. (2013). An evaluation of the effectiveness of individual marketing factors at influencing international student choice of an ESL program in the United States (Doctoral dissertation). Retrieved from ProQuest LLC. (3603798)

Kasworm, C. E. (2003). Setting the stage: Adults in higher education. New Directions for Student Services, 2003(102) 3-10. doi:10.1002/ss.83 
Mazzarol, T. \& Soutar, G. N. (2002). "Push-pull” factors influencing international student destination choice. International Journal of Educational Management, 16(2) 82-90. doi:10.1108/09513540210418403

Middlebrook, G. (1991). Evaluation of student services in ESL programs. In M. C. Pennington (Ed.), Building better English language programs (pp. 135-154). Washington, DC: NAFSA.

Murray, D. (2012). Financial planning and management of resources. In M. Christison \& F. L. Stoller (Eds.), A handbook for language program administrators ( $2^{\text {nd }}$ ed., pp. 243-262). Miami Beach, FL: Alta Book Center.

NAFSA: Association of International Educators (2018a). International students contribute to our economy and American innovation. Retrieved from http://www.nafsa.org/Policy_and_Advocacy/Policy_Resources/Policy_Trends_and_Data/ NAFSA: Association of International Educators (2018b). NAFSA international student economic value tool. Retrieved from http://www.nafsa.org/Policy_and_Advocacy/Policy_Resources/Policy_Trends_and_Data/ Panferov, S. K. (2008). Promoting intensive ESL programs: Taking charge of a market. In C. Coombe, M. L. McCloskey, L. Stephenson, \& N. J. Anderson (Eds.), Leadership in English language teaching and learning (pp. 178-185). Ann Arbor, MI: University of Michigan Press.

Soppelsa, E. F. (2012). Empowerment of faculty. In M. Christison \& F. L. Stoller (Eds.), A handbook for language program administrators ( $2^{\text {nd }}$ ed., pp. 139-158). Miami Beach, FL: Alta Book Center. 
Titscher, S., Meyer, M., Wodak, R., \& Vetter, E. (2000). Methods of text and discourse analysis. Thousand Oaks, CA: Sage Publications.

Toner, M. (2017). Intensive English. International Educator, 26(4), S1-S11. Retrieved from ProQuest LLC (2124689616)

Williams, T. N. (1994). An investigation into factors influencing student selection of intensive English programs in the southeastern United States (Doctoral dissertation). Retrieved from ProQuest Dissertations \& Theses (9502332) 


\section{Appendix A}

\section{Survey Instrument}

Hello, my name is Katie Blanco. I am a graduate student at Brigham Young University and I am conducting this research under the supervision of Professor Mark Tanner from the Department of Linguistics and English Language.

You are invited to participate in this research study of factors that influence students' choice of ESL (English as a Second Language) program. I am interested in discovering what factors influenced your decision to attend the ESL school you are enrolled in.

Your participation in this study will require you to complete the following survey. This should take about 20 minutes of your time. If you complete the survey and provide your email address, you will be entered into a drawing to win one of eight $\$ 15$ Amazon gift cards. The odds of winning a gift card are about 1 in 25 . If you win a gift card, we will email it to you within three weeks after the survey closes. We will not include your email in survey results and will never share your email. You will not be contacted again in the future. If you choose not to participate in the gift card drawing, your participation will be completely anonymous. This survey involves minimal risk to you. The benefits, however, may help to increase knowledge about how ESL programs can improve their marketing to potential students.

You do not have to be in this study if you do not want to be. You do not have to respond to any question that you do not want to answer for any reason. We will be happy to answer any questions you have about this study. If you have further questions about this project or if you have a research-related problem you may contact me, Katie Blanco at [email address] or my advisor, Mark Tanner at [email address].

If you have any questions about your rights as a research participant you may contact the IRB Administrator at A-285 ASB, Brigham Young University, Provo, UT 84602; irb@byu.edu; (801) $422-1461$. The IRB is a group of people who review research studies to protect the rights and welfare of research participants.

The completion of this survey implies your consent to participate. If you choose to participate, please complete this survey by April 27th. Thank you! 
1. What is your country of origin?

2. What is your native language?
Arabic
O Chinese
French
O German
Japanese
Korean
Mongolian
Portuguese
Russian
Spanish
Thai
Vietnamese
Other

3. What is your age?
O 24 or younger
25 or older

4. Sex

O Male

O Female

5. What is your level of English proficiency?
O Beginning
Intermediate
O Advanced
Superior 
6. In your school, how many hours each week do you attend English as a Second Language classes? (Example: 15 hours a week) hours a week

7. Are you an international student on an F1 student visa?

$\mathrm{O}$ Yes

O No

8. What was the main reason you chose to come to your current ESL (English as a Second Language) program?

9. How much do you agree or disagree with the following statements about your motivation to study English?

\begin{tabular}{|c|c|c|c|c|}
\hline & $\begin{array}{l}\text { Strongly } \\
\text { disagree }\end{array}$ & $\begin{array}{c}\text { Somewhat } \\
\text { disagree }\end{array}$ & $\begin{array}{l}\text { Somewhat } \\
\text { agree }\end{array}$ & $\begin{array}{l}\text { Strongly } \\
\text { agree }\end{array}$ \\
\hline $\begin{array}{c}\text { I want to learn English well so that I } \\
\text { can talk with native speakers of } \\
\text { English. }\end{array}$ & 0 & 0 & 0 & 0 \\
\hline $\begin{array}{l}\text { English will help me to get a good } \\
\text { job someday. }\end{array}$ & O & 0 & 0 & O \\
\hline $\begin{array}{l}\text { English will help me to attend an } \\
\text { American university and be } \\
\text { successful in my studies. }\end{array}$ & 0 & 0 & 0 & 0 \\
\hline $\begin{array}{l}\text { I am studying English because it is a } \\
\text { required course in my school or } \\
\text { university. }\end{array}$ & 0 & 0 & 0 & 0 \\
\hline $\begin{array}{l}\text { I need to pass an English proficiency } \\
\text { test (like the TOEFL or an entrance } \\
\text { exam). }\end{array}$ & 0 & 0 & 0 & 0 \\
\hline $\begin{array}{l}\text { My parents want me to learn } \\
\text { English, so I'm here to please them. }\end{array}$ & 0 & 0 & 0 & 0 \\
\hline
\end{tabular}


10. How much did the following ESL (English as a Second Language) program factors influence your choice of ESL program? If a factor statement is not true or does not exist at your school, choose "This factor was not at all important."

\begin{tabular}{|c|c|c|c|c|c|}
\hline & $\begin{array}{l}\text { This factor } \\
\text { was not at } \\
\text { all } \\
\text { important }\end{array}$ & $\begin{array}{l}\text { I considered } \\
\text { this factor, but } \\
\text { it was not very } \\
\text { important }\end{array}$ & $\begin{array}{l}\text { This factor } \\
\text { was } \\
\text { moderately } \\
\text { important }\end{array}$ & $\begin{array}{l}\text { This factor } \\
\text { was } \\
\text { important }\end{array}$ & $\begin{array}{l}\text { This factor } \\
\text { was very } \\
\text { important }\end{array}$ \\
\hline $\begin{array}{l}\text { This ESL program is } \\
\text { very well respected }\end{array}$ & 0 & 0 & 0 & 0 & 0 \\
\hline $\begin{array}{l}\text { The teachers are } \\
\text { respected as excellent } \\
\text { teachers }\end{array}$ & 0 & 0 & 0 & 0 & 0 \\
\hline $\begin{array}{l}\text { This ESL program has } \\
\text { good resources and } \\
\text { amenities (e.g. good } \\
\text { computer lab, modern } \\
\text { equipment, home } \\
\text { stays, travel } \\
\text { opportunities, vacation } \\
\text { break) }\end{array}$ & 0 & $\mathrm{O}$ & $\mathrm{O}$ & 0 & 0 \\
\hline $\begin{array}{c}\text { The cost of the ESL } \\
\text { program is low }\end{array}$ & 0 & $O$ & 0 & $\mathrm{O}$ & 0 \\
\hline $\begin{array}{l}\text { This program offers a } \\
\text { variety of classes }\end{array}$ & 0 & 0 & 0 & 0 & 0 \\
\hline $\begin{array}{l}\text { This ESL program is } \\
\text { part of a larger } \\
\text { university/college I } \\
\text { want to attend }\end{array}$ & 0 & 0 & 0 & 0 & 0 \\
\hline $\begin{array}{l}\text { This ESL program } \\
\text { offers TOEFL } \\
\text { preparation }\end{array}$ & 0 & 0 & 0 & 0 & O \\
\hline $\begin{array}{l}\text { Class times are } \\
\text { convenient }\end{array}$ & 0 & O & 0 & 0 & 0 \\
\hline $\begin{array}{l}\text { ESL class sizes are } \\
\text { small }\end{array}$ & 0 & O & 0 & 0 & 0 \\
\hline
\end{tabular}




\begin{tabular}{|c|c|c|c|c|c|}
\hline $\begin{array}{l}\text { This ESL program has } \\
\text { the right number of } \\
\text { class levels for my } \\
\text { plans }\end{array}$ & ○ & 0 & 0 & O & 0 \\
\hline $\begin{array}{l}\text { This ESL program } \\
\text { provides an intense } \\
\text { learning experience }\end{array}$ & 0 & 0 & 0 & 0 & 0 \\
\hline $\begin{array}{l}\text { This ESL program } \\
\text { provides individual } \\
\text { attention }\end{array}$ & 0 & 0 & 0 & 0 & 0 \\
\hline $\begin{array}{l}\text { Students come from } \\
\text { many different } \\
\text { countries }\end{array}$ & 0 & 0 & 0 & 0 & 0 \\
\hline $\begin{array}{c}\text { There are few students } \\
\text { from my home country } \\
\text { or who speak my first } \\
\text { language }\end{array}$ & 0 & 0 & 0 & 0 & 0 \\
\hline $\begin{array}{l}\text { There are many } \\
\text { students from my } \\
\text { home country or who } \\
\text { speak my first } \\
\text { language }\end{array}$ & 0 & 0 & 0 & 0 & 0 \\
\hline
\end{tabular}

11. How much did the following location factors influence your choice of ESL program? If a factor statement is not true or does not exist at your school's location, choose "This factor was not at all important."

\begin{tabular}{|c|ccccc|}
\cline { 2 - 6 } \multicolumn{1}{c|}{} & $\begin{array}{c}\text { This factor } \\
\text { was not at } \\
\text { all } \\
\text { important }\end{array}$ & $\begin{array}{c}\text { I considered } \\
\text { this factor, but } \\
\text { it was not very } \\
\text { important }\end{array}$ & $\begin{array}{c}\text { This factor } \\
\text { was } \\
\text { moderately } \\
\text { important }\end{array}$ & $\begin{array}{c}\text { This factor } \\
\text { was } \\
\text { important }\end{array}$ & $\begin{array}{c}\text { This } \\
\text { factor was } \\
\text { very } \\
\text { important }\end{array}$ \\
\hline $\begin{array}{c}\text { This city has a good } \\
\text { reputation }\end{array}$ & 0 & 0 & 0 & 0 & 0 \\
\hline $\begin{array}{c}\text { This city has good } \\
\text { weather/climate }\end{array}$ & 0 & 0 & 0 & 0 & 0 \\
\hline $\begin{array}{c}\text { I have a friend or } \\
\text { family member in this } \\
\text { city }\end{array}$ & 0 & 0 & 0 & 0 & 0 \\
\hline
\end{tabular}




\begin{tabular}{|c|c|c|c|c|c|}
\hline $\begin{array}{l}\text { I have a friend or } \\
\text { family member in this } \\
\text { ESL program }\end{array}$ & 0 & 0 & 0 & 0 & 0 \\
\hline $\begin{array}{l}\text { This city is } \\
\text { multicultural }\end{array}$ & $\mathrm{O}$ & O & 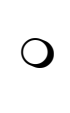 & 0 & 0 \\
\hline $\begin{array}{l}\text { I like the size of this } \\
\text { city }\end{array}$ & O & O & O & 0 & 0 \\
\hline $\begin{array}{l}\text { This community is } \\
\text { safe }\end{array}$ & 0 & O & O & 0 & 0 \\
\hline $\begin{array}{l}\text { This city has } \\
\text { convenient local } \\
\text { transportation }\end{array}$ & 0 & 0 & $\mathrm{O}$ & 0 & 0 \\
\hline $\begin{array}{c}\text { The cost of living is } \\
\text { low in this city }\end{array}$ & 0 & O & O & 0 & 0 \\
\hline $\begin{array}{l}\text { The school is in a safe } \\
\text { part of the city }\end{array}$ & 0 & O & O & 0 & 0 \\
\hline
\end{tabular}

12. How much did the following Student Services factors influence your choice of ESL program? If a factor statement is not true or does not exist at your school, choose "This factor was not at all important."

\begin{tabular}{|c|ccccc|}
\cline { 2 - 6 } \multicolumn{1}{c|}{} & $\begin{array}{c}\text { This factor } \\
\text { was not at } \\
\text { all } \\
\text { important }\end{array}$ & $\begin{array}{c}\text { I considered } \\
\text { this factor, but } \\
\text { it was not very } \\
\text { important }\end{array}$ & $\begin{array}{c}\text { This factor } \\
\text { was } \\
\text { moderately } \\
\text { important }\end{array}$ & $\begin{array}{c}\text { This factor } \\
\text { was } \\
\text { important }\end{array}$ & $\begin{array}{c}\text { This factor } \\
\text { was very } \\
\text { important }\end{array}$ \\
\hline $\begin{array}{c}\text { The school offers help } \\
\text { to find housing } \\
\text { options }\end{array}$ & 0 & 0 & 0 & 0 & 0 \\
\hline $\begin{array}{c}\text { The school offers a } \\
\text { home stay with an } \\
\text { American family }\end{array}$ & 0 & 0 & 0 & 0 & 0 \\
\hline $\begin{array}{c}\text { The school offers out- } \\
\text { of-class activities }\end{array}$ & 0 & 0 & 0 & 0 & 0 \\
\hline $\begin{array}{c}\text { The school offers } \\
\text { airport pickup }\end{array}$ & 0 & 0 & 0 & 0 & 0 \\
\hline
\end{tabular}




\begin{tabular}{|c|ccccc|}
\hline $\begin{array}{c}\text { The school offers } \\
\text { academic and/or } \\
\text { personal counseling }\end{array}$ & O & O & O & O & 0 \\
\hline $\begin{array}{c}\text { The school offers } \\
\text { immigration services }\end{array}$ & O & O & 0 & 0 & 0 \\
\hline $\begin{array}{c}\text { The school offers } \\
\text { meal plans }\end{array}$ & O & 0 & 0 & 0 & 0 \\
\hline
\end{tabular}

13. How much did the following marketing factors influence your choice of ESL program?

\begin{tabular}{|c|c|c|c|c|c|}
\hline & $\begin{array}{l}\text { This factor } \\
\text { was not at } \\
\text { all } \\
\text { important }\end{array}$ & $\begin{array}{l}\text { I considered } \\
\text { this factor, but } \\
\text { it was not very } \\
\text { important }\end{array}$ & $\begin{array}{l}\text { This factor } \\
\text { was } \\
\text { moderately } \\
\text { important }\end{array}$ & $\begin{array}{l}\text { This factor } \\
\text { was } \\
\text { important }\end{array}$ & $\begin{array}{l}\text { This factor } \\
\text { was very } \\
\text { important }\end{array}$ \\
\hline $\begin{array}{l}\text { Referral from a former } \\
\text { ESL student }\end{array}$ & O & $\mathrm{O}$ & $\mathrm{O}$ & $\mathrm{O}$ & $\mathrm{O}$ \\
\hline $\begin{array}{l}\text { Referral from an agent } \\
\text { or recruiter }\end{array}$ & $\mathrm{O}$ & $\mathrm{O}$ & O & O & $\mathrm{O}$ \\
\hline $\begin{array}{l}\text { Referral from a school } \\
\text { counselor }\end{array}$ & $\mathrm{O}$ & O & $\mathrm{O}$ & $\mathrm{O}$ & $\mathrm{O}$ \\
\hline $\begin{array}{l}\text { Referral from an } \\
\text { employer }\end{array}$ & $\mathrm{O}$ & $\mathrm{O}$ & $\mathrm{O}$ & O & O \\
\hline $\begin{array}{c}\text { Referral from a U.S. } \\
\text { embassy }\end{array}$ & $\mathrm{O}$ & $\mathrm{O}$ & $\mathrm{O}$ & $\mathrm{O}$ & O \\
\hline Educational fair & $\mathrm{O}$ & $\mathrm{O}$ & $\mathrm{O}$ & O & O \\
\hline ESL directory list & $\mathrm{O}$ & $\mathrm{O}$ & $\mathrm{O}$ & $\mathrm{O}$ & O \\
\hline $\begin{array}{l}\text { Mailed brochures or } \\
\text { information packets } \\
\text { from the school }\end{array}$ & $\mathrm{O}$ & $\mathrm{O}$ & $\mathrm{O}$ & $\mathrm{O}$ & $\mathrm{O}$ \\
\hline $\begin{array}{c}\text { News article or TV } \\
\text { news report }\end{array}$ & $\mathrm{O}$ & $\mathrm{O}$ & O & $\mathrm{O}$ & O \\
\hline $\begin{array}{l}\text { Newspaper or } \\
\text { magazine } \\
\text { advertisement }\end{array}$ & $\mathrm{O}$ & $\mathrm{O}$ & $\mathrm{O}$ & O & O \\
\hline
\end{tabular}




\begin{tabular}{|c|ccccc|}
\hline $\begin{array}{c}\text { Poster or flier about } \\
\text { the school }\end{array}$ & O & O & O & O & 0 \\
\hline $\begin{array}{c}\text { This ESL school's } \\
\text { website }\end{array}$ & 0 & 0 & 0 & 0 & 0 \\
\hline $\begin{array}{c}\text { Communicating online } \\
\text { with a school } \\
\text { representative }\end{array}$ & 0 & 0 & 0 & 0 & 0 \\
\hline $\begin{array}{c}\text { Watching a video } \\
\text { produced by the } \\
\text { school on YouTube or } \\
\text { another website }\end{array}$ & 0 & 0 & 0 & 0 & 0 \\
\hline $\begin{array}{c}\text { Watching a video } \\
\text { NOT produced by the } \\
\text { school on YouTube or } \\
\text { another web site }\end{array}$ & 0 & 0 & 0 & 0 & 0 \\
\hline
\end{tabular}

14. How much did the following social media sites influence your choice of ESL program?

\begin{tabular}{|c|c|c|c|c|c|}
\hline & $\begin{array}{l}\text { This site } \\
\text { was not at } \\
\text { all } \\
\text { important }\end{array}$ & $\begin{array}{l}\text { I considered } \\
\text { this site, but it } \\
\text { was not very } \\
\text { important }\end{array}$ & $\begin{array}{l}\text { This site } \\
\text { was } \\
\text { moderately } \\
\text { important }\end{array}$ & $\begin{array}{l}\text { This site } \\
\text { was } \\
\text { important }\end{array}$ & $\begin{array}{l}\text { This site } \\
\text { was very } \\
\text { important }\end{array}$ \\
\hline Facebook & 0 & $O$ & 0 & O & 0 \\
\hline Instagram & $\mathrm{O}$ & $\mathrm{O}$ & $O$ & O & O \\
\hline Snapchat & $\mathrm{O}$ & $\mathrm{O}$ & $\mathrm{O}$ & 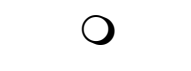 & $\mathrm{O}$ \\
\hline Twitter & $\mathrm{O}$ & $\mathrm{O}$ & O & O & 0 \\
\hline Reddit & $\mathrm{O}$ & $\mathrm{O}$ & O & $\mathrm{O}$ & $\mathrm{O}$ \\
\hline a blog & $O$ & $O$ & $O$ & $\mathrm{O}$ & $O$ \\
\hline Other & 0 & 0 & 0 & $O$ & $\mathrm{O}$ \\
\hline
\end{tabular}


15. How much did the following reasons for studying in the United States influence your choice of ESL program? If a factor statement is not true, choose "This factor was not at all important."

\begin{tabular}{|c|c|c|c|c|c|}
\hline & $\begin{array}{l}\text { This factor } \\
\text { was not at } \\
\text { all } \\
\text { important }\end{array}$ & $\begin{array}{l}\text { I considered } \\
\text { this factor, but } \\
\text { it was not very } \\
\text { important }\end{array}$ & $\begin{array}{l}\text { This factor } \\
\text { was } \\
\text { moderately } \\
\text { important }\end{array}$ & $\begin{array}{l}\text { This factor } \\
\text { was } \\
\text { important }\end{array}$ & $\begin{array}{l}\text { This factor } \\
\text { was very } \\
\text { important }\end{array}$ \\
\hline $\begin{array}{l}\text { I want to study at a } \\
\text { university in the } \\
\text { United States }\end{array}$ & 0 & 0 & 0 & 0 & 0 \\
\hline $\begin{array}{l}\text { I want to get a job in } \\
\text { the United States }\end{array}$ & 0 & 0 & 0 & 0 & 0 \\
\hline $\begin{array}{l}\text { I want to immigrate to } \\
\text { the United States }\end{array}$ & 0 & 0 & 0 & 0 & 0 \\
\hline $\begin{array}{l}\text { I feel it is important } \\
\text { for my future career }\end{array}$ & 0 & 0 & 0 & 0 & 0 \\
\hline $\begin{array}{l}\text { My parents feel it is } \\
\text { important for my } \\
\text { future career }\end{array}$ & 0 & 0 & 0 & 0 & 0 \\
\hline $\begin{array}{l}\text { My purpose is mainly } \\
\text { for vacation }\end{array}$ & 0 & 0 & 0 & 0 & 0 \\
\hline $\begin{array}{l}\text { There is a good } \\
\text { exchange rate between } \\
\text { my money and the } \\
\text { U.S. dollar }\end{array}$ & 0 & 0 & 0 & 0 & 0 \\
\hline $\begin{array}{l}\text { Studying in the U.S. } \\
\text { will help me get a job } \\
\text { back home }\end{array}$ & 0 & 0 & 0 & 0 & 0 \\
\hline $\begin{array}{l}\text { Studying in the U.S. } \\
\text { will help me get } \\
\text { higher social status } \\
\text { back home }\end{array}$ & 0 & 0 & 0 & 0 & 0 \\
\hline
\end{tabular}


You finished all the survey questions!

If you would like to participate in the drawing for a chance to win a \$15 Amazon gift card, please provide your email. We will not share your email. If you do not provide your email, you will not be included in the drawing.

Thank you for your participation in this research.

16. Optional: Please write your email address if you want to be included in the gift card drawing. (Example: john_smith12345@gmail.com). If you do not want to be included, leave this question blank and submit the survey. 


\section{Appendix B}

List of variables that were not associated with program size in the regression analysis.

\section{Demographic Factors}

Country of Origin

Native Language

Age

Sex

\section{Motivation}

I want to learn English well so that I can talk with native speakers of English.

English will help me to attend an American university and be successful in my studies.

I am studying English because it is a required course in my school or university.

I need to pass an English proficiency test (like the TOEFL or an entrance exam).

My parents want me to learn English, so I'm here to please them.

\section{Program Factors}

The teachers are respected as excellent teachers

This ESL program has good resources and amenities (e.g. good computer lab, modern equipment, home stays, travel opportunities, vacation break)

The cost of the ESL program is low

This program offers a variety of classes

This ESL program offers TOEFL preparation

Class times are convenient

ESL class sizes are small

This ESL program has the right number of class levels for my plans

This ESL program provides individual attention

Students come from many different countries

There are few students from my home country or who speak my first language

\section{Location Factors}

This city has good weather/climate

I have a friend or family member in this city

I have a friend or family member in this ESL program

This city is multicultural

I like the size of this city

This community is safe

\section{Student Services Factors}

The school offers help to find housing options

The school offers a home stay with an American family

The school offers out-of-class activities

The school offers academic and/or personal counseling

The school offers immigration services

The school offers meal plans 


\section{Marketing Factors}

Referral from a former ESL student

Referral from an agent or recruiter

Referral from a school counselor

Referral from an employer

Referral from a U.S. embassy

Educational fair

ESL directory list

Mailed brochures or information packets from the school

News article or TV news report

Newspaper or magazine advertisement

Poster or flier about the school

This ESL school's website

Communicating online with a school representative

Watching a video produced by the school on YouTube or another website

Watching a video NOT produced by the school on YouTube or another web site

\section{Social Media Platforms}

Facebook

Instagram

Snapchat

Twitter

Reddit

a blog

\section{Reasons to Study in the United States}

I want to study at a university in the United States

I want to get a job in the United States

I want to immigrate to the United States

I feel it is important for my future career

My parents feel it is important for my future career

Studying in the U.S. will help me get a job back home

Studying in the U.S. will help me get higher social status back home 